\title{
Examining Customer Switching Behavior in Cellular Industry
}

\author{
Sana Malik \\ Research scholar, Department of Management Sciences \\ The Islamia University of Bahawalpur, Pakistan \\ E-mail: sanamalik717@gmail.com
}

Shanayyara Mahmood

Research scholar, Department of Management Sciences

The Islamia University of Bahawalpur, Pakistan

E-mail: shanyfazal@gmail.com

Muhammad Rizwan

Lecturer, Department of Management Sciences

The Islamia University of Bahawalpur, Pakistan

E-mail: rizwan.arshad@iub.edu.pk

Accepted: June 18, 2014

Doi:10.5296/ jpag.v4i2.5840 URL: http://dx.doi.org/10.5296/ jpag.v4i2.5840

\begin{abstract}
Although technology evolves over the year, people take it longer to accept it. The invention of touch screen mobiles or smart phones has now become a need of the hour, simultaneously lowering the demand for keypad mobiles. Our research investigates these switching intentions among people due to the adoption of the new technology. Customer defection is happens when people give up one service provider for another in order to get equipped with the latest gadgets. Survey research method was employed. Questionnaires were distributed among cellular phone users in Bahawalpur. Valid questionnaires $(n=170)$ were filled and returned. Regression analysis was used to analyze the data. PEOU and PU are directly related
\end{abstract}


which has a positive relationship with switching intentions. Also, switching costs and customer loyalty are positively associated. Overall, this research explains that perceived usefulness play a major role in determining customer's switching intentions and that the companies should increase their switching costs to enhance customer loyalty.

Keywords: Switching intentions, switching cost, customer loyalty, cellular industry

\section{Introduction}

Firm managers' understanding of their customers is essential to stop them from switching to another brand or company. According to Dibb and Meadows (2001), relationship marketing has been one of the best approaches that are probable to meet with a lot of interest with respect to switching behavior. When customers abandon one service provider for another it means customer switching or swapping (Garland, 2002). Complete or fractional understanding can exist as explained by Stewart, 1998; Colgate and Hedge, 2001. In complete switching, customers shut all their businesses and accounts and move entirely too some other service provider, (Bolton and Bronkhorst, 1995; Boote, 1998), it is easy to detect. However, on the other hand Partial defection is understood to be partial loss in customer's business and is difficult to point out than total defection (Siddiqui, 2011).

Switching costs as an exit barrier plays a part in the buyer seller relation and it is because of this that customers take into account the switching costs(Weiss and Anderson, 1992; Smith, 1998; Jones et al., 2000), (Jackson, 1985). Many researches focus on the effect of switching costs on customer loyalty in the telecommunication sector (Caruana, 2004; Hu and Hwang, 2006).

For instance, the new price of a cell phone, the buying, the violation penalty etc. will be the switching costs for cell phone users. Therefore, switching costs are costs that prevent customers from buying competing brands in the market. Customer retention is said to be related to higher revenue and lower costs and is a vital element for almost every service provider (Reichheld, 1993; Reichheld and Sasser, 1990).

According to Jones and Sasser (1995) customer switching costs would change in different sectors of the industry. As with the automobile industry, customers will have low switching costs if products or services can be offered by many suppliers.

However, if services or products are only managed by a few suppliers, for example in the airlines, switching costs for customers would be high.

Intentions are affected by attitudes, perceived control on behavior and subjective norms (Ajzen, 1991). Those who have negligible problems with their service providers, rarely show Switching behavior. Also that, definitive problems are less often the cause of switching as compared to indefinite problem (Zeithaml, Berry \& Parasuraman, 1996).

The variables under discussion are perceived ease of use, perceived usefulness, switching intentions, switching costs and customer loyalty, where perceived risks is acting as a 
moderator in this article.

Perceived ease of Use is the understanding that a technology is easy to use, while perceived usefulness is the person's belief about the improvement in performance with the use of a technology (Davis, 1989).This study also investigates perceived ease of use and perceived usefulness and their respective effects on switching intentions.

Perceived risks can be one of the many causes of customer purchase intention in spite of switching cost being the only cause. The idea of perceived risks points out that customers psychology feel uncertain when they cannot foresee the result of a purchase and it acts as a moderator between switching costs and customer loyalty in our study.

Customer loyalty is a strong devotion to purchase and patronize a favored product/service again and again, despite extraneous efforts to cause switching behavior (Oliver, 1997). Our study will also show an effect of switching costs on customer loyalty.

\section{Literature Review}

\subsection{Switching Intentions}

Customer defection occurs when customers switch between service providers in the service environment (Garland, 2002). It can be total or partial (Stewart, 1998; Colgate and Hedge, 2001). Total defection is normally easily pointed out due to their magnitude. While partial defection is defined as a portion loss of a customer's business and is more difficult to point out than total defection (Siddiqui, 2011).

From a customer satisfaction outlook; estimates tell that of all defecting customers, 35 percent owing to "uncontrollable external factors"; rest of the defections is caused by "controllable internal factors" relating to the organization's customer relations.

Price, product problems, low service quality, problem resolution, merger and location/expediency are listed as controllable factors (Trubik and Smith, 2000). Customers can be retained by better policies for these factors. Purposes are themselves shaped by attitudes, subjective standards and apparent interactive control (Ajzen, 1991). The three elements of behavioral intents are each based on an underlying belief structure: behavioral, normative, and control beliefs. In their particular masses, behavioral beliefs produce a favorable or unfavorable attitude toward the behavior; normative beliefs result in a perceived social pressure or subjective norm; and control beliefs give rise to perceived behavioral control with regard to performing the behavior.

Although, relationship quality is an important driver of switching intentions, but switching costs and attractiveness of switching are its significant determinants (Wieringa and Verhoef, 2007).

\subsection{Perceived Ease of Use and Perceived Usefulness}

The two most important factors in explaining technology are the perceived ease of use (PEOU) and perceived usefulness (PU). The interpretation that a specific system or technology is easy to use is termed as Perceived ease of Use, while perceived usefulness is 
the extent to which a person believes that using a technology will improve his or her performance level (Davis, 1989; Rizwan et al., 2013).

Venkatesh \& Davis, (2000) examined the importance and wide application of both in technology-driven contexts. Therefore, our study also shows the effect of perceived ease of use and perceived usefulness on switching intentions (Ching-Fu Chen and Wei-Hsiang Chao, 2008).

H1: There is a positive association between perceived ease of use and perceived usefulness.

H2: There is a positive association between perceived usefulness and switching intentions.

\subsection{Switching costs}

A cost used in changing supplier which describes different financial and non-financial costs is known as switching cost (Matthews and Murray, 2007). It is measured from the cost which is derived from switching to another provider (Lee and Cunningham, 2001).

First time cost faced by the buyer when switching from one supplier product to another Porter (1980, p. 10). Switching costs can be defined as the additional costs required dismissing the current relationship and acquiring an alternative. Switching costs, however, may comprise psychological and emotional costs (Keaveney, 1995). Psychological exit barrier cost occurs when individual understanding and trust have been built up over a period of time between the service provider and the customer.

The relationships between switching costs and customers' switching intentions have been investigated by researchers. Customers usually avoid changing service provider if the switching cost is high Fornell (1992). Usually customers get disappointed from not leaving the current organization due to high perceived risk they have to face in switching (Lees et al., 2007). Therefore, dissatisfied customers remain stick to their current organization because of high switching cost Gronhaug and Gilly (1991).

H3: There is a negative association between switching costs and switching intentions.

\subsection{Customer loyalty}

A commitment to buy or purchase a product regularly in future from a particular organization is said to be customer loyalty (Oliver, 1999, p. 34). A feeling of liking for a company's people, products, or services is known as customer loyalty Jones and Sasser (1995, p. 94). There are two meanings of Customer loyalty: long-term and the short-term loyalty (Jones \& Sasser, 1995).

True loyalty only exists when repeat patronage coexists with a high relative attitude. Customers with the high commitment do not switch to other services or product easily while the customers with low commitment easily switch to other product when offered better alternative. As the study focuses on long-term loyalty that establishing a relationship with customers is beneficial for service providers. The mobile service market is highly saturated and profit margins are stagnant in Taiwan. Therefore, retaining existing customers than recruiting new ones is better (Ahmad \& Buttle, 2002; Fornell, 1992). An effect of customer 
loyalty on switching intentions has also been shown in the Studies. Furthermore, Burnham et al. (2003) stated that switching costs generates passive loyalty. To retain a customer it is beneficial for service provider to establish good relationship with a customer that results in a long-term loyalty (Rizwan et al., 2013).

H4: There is a negative association between customer loyalty and switching intentions.

As mentioned in the past studies, switching costs are positively associated with the customer loyalty in telecommunication sector (Hu and Hwang, 2006; Ibanez et al., 2005; Caruana, 2004). Customers will have the high willingness to repatronate and bear the dissatisfaction response when they have high switching costs toward the technology. That is, switching costs are positively associated with customer loyalty.

H5: There is a positive association between switching costs and customer loyalty.

\subsection{Perceived Risks}

The concept of perceived risks denotes that the customers who cannot forecast the outcome of a purchase decision are having a feeling of psychological ambiguity (Bauer, 1960). It was founded by Cox (1967) that the customers' ambiguity about goal satisfaction are affected by perceived risks and supposed that the customers cannot be satisfied once the product or services have been purchased. Due to the institutional trust and economic incentives perceived risks can be reduced, Salam et al. (2003).Obviously, perceived risks are negatively associated with trust. Carter et al. (2009) used trust as a moderator; he demonstrates that the trust is high when the relationship between switching costs and customer loyalty is stronger.

Customer having no transactional experiences or have suffered negative experience in past perceives high risks and usually are new or dissatisfied customers. That is the only reason: their customers' switching cost is low. Therefore, customers facing lower risk perception will purchase again and again and their switching costs can be great. As a result, customer loyalty will also be high.

In addition to this, customers will purchase less that are having high perceived risks. These types of customers are always unwilling to make a relationship even though they have high switching costs. Therefore, the association between switching costs and customer loyalty is affected by perceived risks.

This study shows that how perceived risks affect switching costs and customer loyalty acting as a moderator.

H6: The association of switching costs and customer loyalty will be moderated by perceived risks.

H6a. For customers with low perceived risks, Switching costs are positively associated with customer loyalty.

H6b. For customers with high perceived risks, Switching costs are negatively associated with customer loyalty. 


\section{Research Methodology}

The current research is descriptive in its nature. Describing something, some occurrence or any specific situation is termed as descriptive research. Also, descriptive researches are those researches that depict the current situation instead of inferring and making conclusions (Creswell, 1994). Confirmation of the established hypotheses that reveal the existing situation is the basic objective of descriptive research. It provides information about the present conditions and concentrates on the past and current for instance value of life in a society or customer outlooks towards any marketing pursuit (Kumar, 2005).

\subsection{Sample/Data}

A sample of 170 respondents will ask to participate in a self-administered questionnaire, in order to collect the data for understanding the situation about acceptance of touch screen mobile. The population for the current research is mobile users in Bahawalpur/Pakistan.

The current study uses a non-probability sampling technique that is convenience sampling. A sampling technique that collects the significant information from the conveniently available sample study is known as convenience sampling (Zikmund, 1997). This type of sampling is normally helps in collecting large number of completed surveys speedily and with economy (Lym et al., 2010).

\subsection{Instrument and Measures}

The survey instrument of the current study address two major purposes: First is to analyze the relationship of different variables in the adoption of touch screen mobile. Second, to collect information about the different characteristics of the respondents that can be used to understand the variations in different categories.

The survey instrument contains two sections. Section 1 includes different personal and demographic variables. This section will obtain the respondent's information about gender, age, income, education and status. Section 2 includes the latent variables that are important in the current study. These variables includes perceived usefulness, perceived ease of use, switching intentions, switching cost, customer loyalty and perceive risk. This section of the study is developed based on the past literature and already used questionnaires (Table 1).

The scales of the study were adopted from the previous literature and published studies. The first three variables of the study were perceived ease of use, perceived usefulness and switching intentions. Perceived ease of use has six items, perceived usefulness and switching intentions have 3 items and were taken from Ching-Fu Chen and Wei-Hsiang Chao (2010). The next variables are switching cost, customer loyalty and perceived risk having three items taken from Gurjeet Kaur, R.D sharma and Neha Mahajan (2011), Yung-Shen Yen (2010).

\subsection{Procedure}

The questionnaire was distributed among 170 respondents in Bahawalpur. These respondents are selected based on the criteria above mentioned. Before giving the questionnaire, the purpose of study and questions were explained to the respondents so they can easily fill the 
questionnaire with relevant responses.

After collecting the completed questionnaires, these questionnaires were coded and entered into SPSS sheet for further analysis.

\subsection{Reliability Analysis}

All the variables of our questionnaire were reliable as their Cronbach Alpha values were more than acceptable and recommended value 0.50 by Nunnally (1970) and 0.60 by Moss et al. (1998). This shows that all the 27 items were reliable and valid to measure the opinions of consumers towards switching intentions.

Table 1: Reliability of Measurements Instrument

\begin{tabular}{|l|l|l|}
\hline Scales & Items & Cronbach Alpha \\
\hline Perceived Ease of Use & 6 & 0.871 \\
\hline Perceived Usefulness & 3 & 0.752 \\
\hline Switching Intentions & 3 & 0.758 \\
\hline Switching Cost & 5 & 0.569 \\
\hline Customer Loyalty & 5 & 0.801 \\
\hline Perceived Risk & 5 & 0.734 \\
\hline
\end{tabular}

\section{Results and Analysis}

\subsection{Profile of the Respondents}

Personal and demographic information such as gender, age, education level and status are presented in the following table (Table 3). 


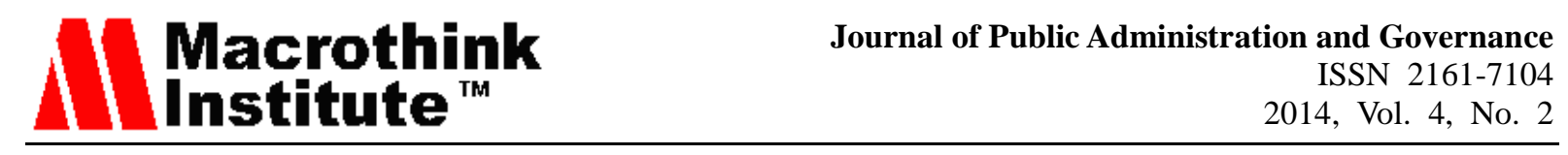

Table 2: Profile of the Respondents

\begin{tabular}{|c|c|c|c|}
\hline & Category & Frequency & Percentage \\
\hline Variable & & & \\
\hline Gender & $\begin{array}{l}\text { Male } \\
\text { Female }\end{array}$ & $\begin{array}{l}90 \\
80\end{array}$ & $\begin{array}{l}52.9 \\
47.1\end{array}$ \\
\hline Age & $\begin{array}{l}\text { Below } 20 \text { years } \\
20-30 \text { years } \\
30-40 \text { years } \\
\text { Above } 40 \text { years }\end{array}$ & $\begin{array}{l}66 \\
101 \\
1 \\
2\end{array}$ & $\begin{array}{l}38.8 \\
59.4 \\
0.6 \\
1.2\end{array}$ \\
\hline Education & $\begin{array}{l}\text { Matriculation } \\
\text { Inter } \\
\text { Bachelor } \\
\text { Master } \\
\text { MS/M. Phil } \\
\text { PhD }\end{array}$ & $\begin{array}{l}3 \\
24 \\
125 \\
9 \\
8 \\
1\end{array}$ & $\begin{array}{l}1.8 \\
14.1 \\
73.5 \\
5.3 \\
4.7 \\
0.6\end{array}$ \\
\hline Status & $\begin{array}{l}\text { Student } \\
\text { Employed } \\
\text { Businessman } \\
\text { Unemployed } \\
\text { Housewife }\end{array}$ & $\begin{array}{l}162 \\
5 \\
2 \\
0 \\
1\end{array}$ & $\begin{array}{l}95.3 \\
2.9 \\
1.2 \\
0 \\
0.6\end{array}$ \\
\hline
\end{tabular}

\section{Hypothesis Testing}

\subsection{Perceived usefulness and Perceived Ease of use}

According to the results of the study, perceived ease of use has a significant, positive effect on perceived usefulness $(\beta=0.650, p<0.01)$. That means the

Perceived ease of use contributes more than $65 \%$ toward perceived usefulness. The 
regression validates the $\mathrm{H} 1$.

\subsection{Perceived usefulness and switching intentions}

The regression results of the study confirm the significant positive relationship between Perceived usefulness and Switching Intention with $(\beta=0.561)$ and $(\mathrm{p}<0.01)$. According to these results, Perceived usefulness contributes more than $56 \%$ to Switching Intentions. These results of the study validate $\mathrm{H} 2$.

\subsection{Switching costs and Switching Intentions}

The results of the current study shows no significant relationship between these two variables with $(\beta=0.127)$ and $(p>0.05)$. Based on these results, we reject $\mathrm{H} 3$ and conclude that the study did not find significant relationship switching costs with switching intentions.

\subsection{Customer loyalty and Switching Intentions}

Regression Analysis of the switching intention model shows that there is no significant relationship between customer loyalty and Switching Intentions $(\beta=-0.141)$ and $(p>0.01)$. The results suggest that there is a negative, insignificant between the two variables.

\subsection{Switching cost and Customer loyalty}

Linear regression is used in this study to observe the relationship between switching costs and customer loyalty. Customer loyalty is a dependent variable where as switching cost is an independent variable. The results shows that switching costs are positively associated with customer loyalty $((\beta=0.355)$ and $(\mathrm{p}<0.01)$. Hence, $\mathrm{H} 5$ is supported.

\subsection{Perceived risks as a moderator}

Regression analysis of the study does not confirm the moderation of perceived risk between the relationship of switching cost and customer loyalty. The impact of switching cost and perceived risk were significant (Beta $=0.327$ and $\operatorname{sig}=0.003$ and Beta $=0.248$ and sig $=0.002$ respectively) on customer loyalty but the interaction term (switching cost $\mathrm{x}$ perceived risk) was not significant with $\mathrm{B}=0.028$ and $\mathrm{sig}=0.77$. The absence of interaction was also confirmed by seeing the value of $\mathrm{R}^{2}$ change. The $\mathrm{R}^{2}$ change was also insignificant with significance value is greater than 0.05 . 
Table 3: Regression Results

\begin{tabular}{|l|l|l|l|l|l|l|}
\hline $\begin{array}{l}\text { Hypothes } \\
\text { is }\end{array}$ & Model Variables & Estimate & S.E. & C.R. & P & Results \\
\hline H1 & PU $\longleftarrow$ PEOU & 0.647 & 0.133 & 11.076 & 0.000 & supported \\
\hline H2 & SI $\longleftarrow$ PU & 0.561 & 0.066 & 8.467 & 0.000 & $\begin{array}{l}\text { Supported } \\
\text { H3 }\end{array}$ \\
SI $\longleftarrow$ SC & 0.166 & 0.100 & 1.661 & 0.099 & Not supported \\
\hline H4 & CL $\longleftarrow$ SI & -0.466 & 0.077 & -1.844 & 0.077 & Not supported \\
H5 & CL $\longleftarrow$ SC & -0.141 & .095 & 4.918 & 0.000 & supported \\
\hline
\end{tabular}

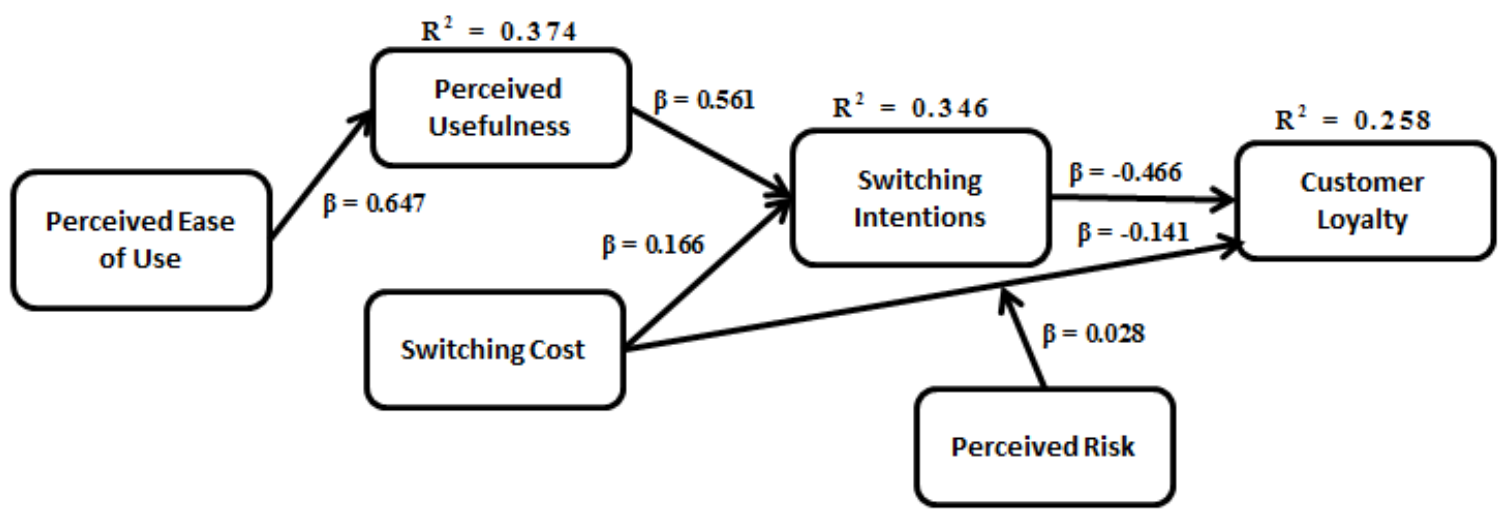

Figure 1: Structural Model Results

\section{Discussion}

The basic aim of our research has been to investigate the switching intentions among the customers from keypad to Touch screen mobiles. Current study formulated a model to include switching intentions as an antecedent to perceived usefulness. The results obtained from the analysis permitted us to verify the established hypotheses and to understand the relationship between different variables of our research model. Now individually we discuss these findings and their implications in the following.

Perceived usefulness is a major criterion for the customers to select Touch screen Mobiles as many believe it to enhance their performance especially in developing city like Bahawalpur. PEOU and PU are almost always together that is one depends on the other, thereby producing a bundle of advantages and benefits for the customers using it.

The higher the perceived usefulness the greater will be the switching intentions of the people for a particular technology/system in this case the touch screen mobiles. We also found that higher the switching cost higher will be the customer loyalty, meaning that people will tend to 
stay at their current technology that is keypad mobiles as Bahawalpur is not a very well off city and factors economics come in play. This also explains why greater switching cost tends to decrease switching intentions as well. Switching cost in telecommunication is not as important because of many promotional offers and special discounts by mobile companies. Also, the perceived risk is low since mobile companies are well known to customers and the cost of phones is moderated and same for all customers.

The ability of the touch screen mobile to satisfy the ever increasing needs of the customer is being fulfilled to some extent the switching cost being higher for the costumer make it difficult for them to defect from one brand to another. As the population of our city is not very large and this survey is also conducted on a small scale, the results could be more fruitful if done on a mass level providing us with exceptional results about the intentions to switch.

Also there is a need for awareness among all the age groups. As older people tend to use keypad mobiles more as compared to the younger generation, it is difficult for many to use the new system / technology, as it needs sufficient time and knowledge to learn using the touch screen mobiles.

Another fact that comes onto surface is that customer loyalty is quite high even if the people are dissatisfied as they consider that the cost of using touch screen mobiles would be higher than their dissatisfaction level. We can say that although there is willingness to accept the usefulness of the new technology, the higher switching costs make people to remain loyal to their current services and thus, intentions to move to other service providers are also low. These reasons and arguments prove the strong relationship between customer loyalty and switching intentions.

\section{Limitations and Future Research}

The current study has some limitations including a smaller sample size. It could have been larger in order to get more responses from the population and made our research more concrete. Also, only the people in Bahawalpur have been targeted where majority of the respondents were University students. We could have extended our study to various areas and regions. Our research examines the switching intentions among the people but only a particular segment of the total population has been targeted.

\section{REFERENCES}

Aydin, S. and zer, G. (2005), "How switching costs affect subscriber loyalty in the Turkish mobile phone market: an exploratory study", Journal of Targeting, Measurement and Analysis for Marketing, Vol. 14 No. 2, pp. 141-55.

Ajzen, I. (1985). From intentions to actions: A theory of planned behavior. In J. Kuhl \& J. Beckmann (Eds.), Action-control: From cognition to behavior (pp. 11-39). New York: Springer. 
Ajzen, I. (1991). The theory of planned behavior. Organizational Behavior and Human Decision Processes, 50(2), 179-211.

Ajzen, I. and Fishbein, M. (1980), Understanding Attitudes and Predicting Social Behavior, Prentice-Hall, Englewood Cliffs, NJ.

Bamberg, S., Ajzen, I., \& Schmidt, P. (2003). Choice of travel mode in the theory of planned behavior: The roles of past behavior, habit, and reasoned action. Basic and Applied Social Psychology, 25(3), 175-187.

Bamberg, S., \& Schmidt, P. (2003). Incentives, morality or habit? Predicting students' car use for university routes with the models of Ajzen, Schwartz and Triandis. Environment and Behavior, 35(2), 264-285.

Bauer, R.A. (1960), “Consumer behavior as risk taking”, in Hankcock, R.S. (Ed.), Dynamic Marking for a Changing World, American Marketing Association, Chicago, IL, pp. 389-98.

Bolton, R. and Bronkhorst, T. (1995), "The relationship between customer complaints to the firm and subsequent exit behavior", in Kardes, F.R. and Sujan, M. (Eds), Advances in Consumer Research, Vol. 22, Association for Consumer Research, Provo, UT, pp. 94-100.

Bolton, R.N., Lemon, K.N. and Verhoef, P.C. (2004), "The theoretical underpinnings of customer asset management: a framework and propositions for future research", Journal of the Academy of Marketing Science, Vol. 32 No. 3, pp. 271-92.

Boote, J. (1998), "Towards a comprehensive taxonomy and model of consumer complaining behavior", Journal of Customer Satisfaction, Dissatisfaction and Complaining Behavior, Vol. 11, pp. 141-9.

Burner, G.C. \& Kumar, A. (2005). Explaining consumer acceptance of handheld Internet devices. Journal of Business Research, 58(5), 553-568

Burnham, T.A., Frels, J.K. and Mahajan, V. (2003), "Consumer switching costs: a typology, antecedents and consequences", Journal of the Academy of Marketing Science, Vol. 31 No. 2, pp. 109-26.

Cox, D.F. (1967), "Risk handling in consumer behavior - an intensive study of two cases", in Cox, D.F. (Ed.), Risk-taking and Information Handling in Consumer Behavior, Harvard University Press, Boston, MA. De Ruyter, K., Wetzels, M. and Bloemer, J. (1998), "On the relationships between perceived service quality, service loyalty and switching costs", International Journal of Service Industry Management, Vol. 9 No. 5, pp. 436-53.

Caruana, A. (2002), "Service loyalty: the effects of service quality and the mediating role of satisfaction”, European Journal of Marketing, Vol. 36 Nos 7/8, pp. 811-28.

Colgate, M. and Hedge, R. (2001), "An investigation into the switching process in retail banking services”, International Journal of Bank Marketing, Vol. 19 No. 5, pp. 201-12.

Colgate, M. and Lang, B. (2001), "Switching barriers in consumer markets: an investigation of the financial services industry", Journal of Consumer Marketing, Vol. 18 No. 4, pp. 
$332-47$.

Colgate, M., Tong, V.T., Lee, C.K. and Farley, J.U. (2007), "Back from the brink: why customers stay", Journal of Service Research, Vol. 9 No. 3, pp. 211-28.

Davis, F. D. (1989). Perceived usefulness, perceived ease of use, and user acceptance of information technology. MIS Quarterly, 13(3), 319-340.

Carter, M., Klein, R., Thatcher, J.B. and Wright, R. (2009), "Switching costs and loyalty: understanding how trust moderates online consumers' ties to merchants", Proceedings of the 8th Annual Workshop on HCI Research in MIS, Phoenix, Arizona. Caruana, A. (2004), "The impact of switching costs on customer loyalty: a study among corporate customers of mobile telephony", Journal of Targeting, Measurement and Analysis for Marketing, Vol. 12 No. 3, pp. 256-68.

Creswell, J.W. (1994) Research Design: Qualitative \& Quantitative Approaches. London: SAGE Publications.

Dick, A.S. and Basu, K. (1994), "Customer loyalty: toward an integrated conceptual framework", Journal of the Academy of Marketing Science, Vol. 22 No. 2, pp. 99-113.

Fishbein, M., \& Ajzen, I. (1975). Belief, attitude, intention and behavior: An introduction to theory and research. Reading, MA: Addison-Wesley. Fornell, C., \& Larcker, D. F. (1981). Evaluating structural equations with unobservable variables and measurement form. Journal of Marketing Research, 18(1), 39-50.

Fornell, C. and Larcker, D.F. (1981), "Evaluating structural equation models with unobservable variables and measurement error", Journal of Marketing Research, Vol. 18 No. 1, pp. 39-50.

Garland, R. (2002), "Estimating customer defection in personal retail banking, International Journal of Bank Marketing, Vol. 20 No. 7, pp. 317-24.

Jackson, B.B. (1985), Winning and Keeping Industrial Customers: The Dynamics of Customer Relationships, DC Heath and Company, Lexington, MA. Hu, A.W. and Hwang, I. (2006), "Measuring the effects of consumer switching costs on switching intention in Taiwan mobile telecommunication services", The Journal of American Academy of Business, Vol. 9 No. 1, pp. 75-85.

Jones, T.O. and Sasser, W.E. (1995), "Why satisfied customer defect", Harvard Business Review, Vol. 73 No. 6, pp. 89-99.

Jones, M.A., Mothersbaugh, D.L. and Beatty, S.E. (2000), "Switching barriers and repurchase intentions in services", Journal of Retailing, Vol. 76 No. 2, pp. 259-74.

Keaveney, S.M. (1995), "Customer switching behavior in service industries: an exploratory study”, Journal of Marketing, Vol. 69, April, pp. 71-82.

Keaveney, S.M. (1995), "Customer switching behavior in service industries: an exploratory study”, Journal of Marketing, Vol. 59 No. 2, pp. 71-82. 
Lee, J., Lee, J. and Feick, L. (2001), "The impact of switching costs on the customer satisfaction-loyalty link: mobile phone service in France", Journal of Services Marketing, Vol. 15 No. 1, pp. 35-48.

Lee, J., Lee, J. and Feick, L. (2001), "The impact of switching costs on the customer satisfaction-loyalty link: mobile phone service in France", Journal of Services Marketing, Vol. 15 No. 1, pp. 35-48.

Morgan, R.M. and Hunt, S.D. (1994), "The commitment-trust theory of relationship marketing”, Journal of Marketing, Vol. 58, July, pp. 20-38.

Morgan, R.M. and Hunt, S.D. (1994), "The commitment-trust theory of relationship marketing”, Journal of Marketing, Vol. 58, July, pp. 20-38.

Moss, S., Prosser, H., Costello, H. (1998). Reliability and validity of the PAS-ADD Checklist for detecting psychiatric disorders in adults with intellectual disability. Journal of Intellectual Disability Research. 42, 173- 183.

Nunnally, JC. (1970). Introduction to Psychological Measurement. New York: McGraw-Hill.

Oliva, T.A., Oliver, R.L. and MacMillan, I.C. (1992), "A catastrophe model for developing service satisfaction strategies", Journal of Marketing, Vol. 56 No. 3, pp. 83-95.

Oliver, R.L. (1999), “Whence consumer loyalty?”, Journal of Marketing, Vol. 63, special issue, pp. 33-44.

Reichheld, F. (1993), "Loyalty-based management", Harvard Business Review, Vol. 71, March-April, pp. 64-73.

Rizwan, M., Akbar, I., Muqtadir, A., Shafique, U., Zia, H., Naseer, W. and Amin, S. A. (2013) Impact of Brand Switching, Brand Credibility, Customer Satisfaction and Service Quality on Brand Loyalty, IOSR Journal of Business and Management, Vol. 1 (special issue), 12-20

Reichheld, F. and Sasser, W. (1990), "Zero defections: quality comes to service”, Harvard Business Review, Vol. 68 No. 5, pp. 105-11.

Rizwan, M., Imran, M., Qayyum, A., Yousaf, M., Qaiser, S., Afzal, S. and Fatima, N. (2013) Consumer's purchase intention towards Counterfeit Mobile Phones, IOSR Journal of Business and Management, Vol. 1 (special issue), 36-43

Salam, A.F., Rao, H.R. and Pegels, C.C. (2003), "Consumer-perceived risk in e-commerce transactions", Communications of the ACM, Vol. 46 No. 12, pp. 325-31.

Stewart, K. (1998), “An exploration of customer exit in retail banking, International Journal of Bank Marketing, Vol. 16 No. 1, pp. 6-14.

Siddiqui, K. (2011), "Personality influences customer switching", International Journal of Contemporary Research in Business, Vol. 2 No. 10, pp. 363-72.

Trubik, E. and Smith, M. (2000), "Developing a model of customer defection in the Australian banking industry”, Managerial Auditing Journal, Vol. 15 No. 5, pp. 199-208. 


\section{Ml Macrothink}

Journal of Public Administration and Governance ISSN 2161-7104 2014, Vol. 4, No. 2

Venkatesh, V., \& Davis, F. D. (2000). A theoretical extension of the technology acceptance model: Four longitudinal field studies. Management Science, 46(2), 186-204.

Venkatesh, V., \& Davis, F. D. (2000). A theoretical extension of the technology acceptance model: Four longitudinal field studies. Management Science, 46(2), 186-204.

Weiss, A.M. and Anderson, E. (1992), "Converting from independent to employee sales forces: the role of perceived switching costs", Journal of Marketing Research, Vol. 29 No. 1, pp. 101-15.

Wieringa, J.E. and Verhoef, P.C. (2007), "Understanding customer switching behavior in a liberalizing service market”, Journal of Service Research, Vol. 10 No. 2, pp. 174-86.

Zeithaml, V.A., Berry, L.L. and Parasuraman, A. (1996), “The behavioral consequences of service quality", Journal of Marketing, Vol. 60 No. 2, pp. 31-46

Zeithaml, V.A., Parasuraman, A. and Berry, L.L. (1996), "The behavioral consequences of service quality", Journal of Marketing, Vol. 60, April, pp. 31-46. Marketing, Vol. 62 No. 1, pp. 33-47.

Zikmund, W.R. (1997). Business Research Methods (5th Ed.), Texas: The Dryden Press. 